\title{
Annual forage legumes in dryland agricultural systems of the West Asia and North Africa Regions: research achievements and future perspective
}

\author{
S. Ates, D. Feindel, A. El Moneim and J. Ryan \\ International Center for Agricultural Research in the Dry Areas (ICARDA), Tel Hadya, Aleppo, Syria
}

\begin{abstract}
Forage legumes are vitally important to animal production in the dryland farming systems of the Mediterranean region. Of the diverse forage-legume species adapted to the Mediterranean climate, vetches, (Vicia spp.), chicklings (Lathyrus spp.), annual medics (Medicago spp), clovers (Trifolium spp.) and species of the Lupinus, Lotus, Onobrychis, Hedysarum and Ornithopus genera are considered to be the most agronomically important and economically valuable species for the region. Adoption of perennial self-regenerating medic (Medicago spp.) has been limited because of technical difficulties, but annual vetch (Vicia spp.) has the greatest potential as a viable animal-feed source and a rotation crop with cereals. Some forage legumes survive harsh conditions by their unique underground growth habit, for example, V. amphicarpa and Lathyrus ciliolatus. Efforts to improve forage legumes have been based on both management/cultural factors and breeding. Research based on several long-term barley- and wheat-based rotation trials has demonstrated the viability of forage legumes, especially vetch, in the region's improved farming system. An additional benefit to such legumes is the enhancement of soil quality, that is, soil fertility, soil organic matter and soil physical properties. Thus, the development of forage legumes is essential to agricultural sustainability in the Mediterranean region and in other dryland cereal-growing areas of the world where grazing livestock is a dominant enterprise. To build upon the considerable research conducted on forages, intensified efforts are needed to develop locally adapted forage cultivars, to provide economic assessment of forages in cropping systems and to promote technology transfer at the farm and community level.
\end{abstract}

Correspondence to: Dr S. Ates, ICARDA, P.O. Box 950764, Amman 11195 , Jordan.

E-mail: s.ates@cgiar.org

Received 17 December 2012
Keywords: dryland forage legumes, rainfed cropping, vetches, chicklings, Medicago, soil quality, Mediterranean agriculture

\section{Introduction}

With the world's population predicted to exceed 9 billion people by the middle of the 21 st century, serious questions are again being raised about the capacity of the earth to sustain such a population without doing irrevocable harm to the natural resources that underpin food production, while also maintaining the environment (Roy et al., 2006). The challenges to mankind today are more acute than ever and range from the biophysical (water scarcity, land degradation, biodiversity loss) to the socio-economic (rapid population growth - especially in developing countries, poverty, inadequate nutrition and health care, substandard education and poor infrastructure). The daunting challenges for society at large have been forcefully articulated by scientists such as Norman Borlaug, the father of the Green Revolution (Borlaug, 2007), and by the popular press (Cribb, 2010). The task of feeding tomorrow's world population will require a radically new way of thinking in terms of the application of science and technology (Godfray et al., 2010). Given their importance in global nutrition, greater efforts will need to be made in cereal production in terms of both yields and quality (Doberman and Cassman, 2002). In considering cereal output, one has to consider the production system as a whole: that is, the crops grown in rotation, especially forage crops that support animal populations, and how they are managed.

Given the limited supply of arable land in the world available for further exploitation, and the unrelenting pressure on land use, considerable interest has developed in recent decades in improving and sustaining the productivity of dryland regions in developing countries (Lal, 2002). Dryland semi-arid agriculture had attracted relatively little research attention 
compared with temperate regions of the world. Because of the inherent fragility of dryland ecosystems, their capacity for agricultural production without resource degradation is a major concern (Stewart and Robinson, 1997). Sustainability of these cropping systems implies a system that continues to meet food and fibre production needs (Ryan et al., 2008a). In the context of the Mediterranean region, characterized by a cool moist season where rainfed cropping can be practised, followed by a long dry season (Kassam, 1991), the concept of sustainability hinges around the system of growing the crop, i.e., the rotation. Crop rotations were evidently debated and practised in the Mediterranean region as far back as Roman times (Karlen, 1994). Despite the antiquity of the practice of crop rotation, its merits are still valid.

In traditional Mediterranean agriculture, fallow has been a common practice to conserve moisture, and cereals have long been alternated with food and feed legumes (Cooper et al., 1987). Cereal production was integrated with animal production, mainly sheep (Ovis aries) and goats (Capris hircus) in drier areas. As with human populations in the region, the populations of small ruminants have greatly increased (Hopfenberg and Pimentel, 2001; Aw Hassan et al., 2010). Thus, not only is food production for humans a pressing concern, but so also is the provision of feed for animals, especially given the widespread degradation of rangelands in the West Asia and North Africa (WANA) regions (Le Houerou, 2000; Ates and Louhaichi, 2012). A recent assessment of the Arab Near East highlighted the serious biophysical and socio-economic constraints to development facing the Middle East region as a whole (Khouri et al., 2011). A possible solution to animal feed deficits is the development of indigenous forage legumes, for grazing and stored feed, and in some cases, the introduction of new species or cultivars (Thompson et al., 1992; Louhaichi and Tastad, 2010).

Given the need to expand cereal production in the drylands of WANA, and simultaneously to enhance animal feed and forage, the rotational system became a major platform of the research agenda of the International Center for Agricultural Research in the Dry Areas (ICARDA) both in Syria and in conjunction with the national research programmes of the broad Mediterranean region. Therefore, rotations that involved both cereals (barley and wheat) and feed or forage legumes were common features in the trials that were conducted (Papastylianou, 1993; Harris, 1995; Jones and Singh, 2000a,b; Yau et al., 2003; Pala et al., 2008). A comprehensive review of research conducted with the common cereal-based rotations in the WANA region was presented by Ryan et al. (2008a). More recent publications have shown the importance of feed and forage legumes in wheat-based systems in the more-favourable rainfall zones (Ryan et al., 2010; Christiansen et al., 2011) and in the drier barley-based systems (Ryan et al., 2012), thus establishing the link between cereal output and the grazing animal.

This review, focusing mainly on the research that has emanated from ICARDA, highlights the role of annual sown forage legumes with reference to selfregenerating medics in grazing pastures. Major attention is given to these forage legumes as feed sources, their agronomic performance in the dryland cropping systems of WANA and their value in rotations, highlighting the interactions in rotation with cereals, improvements in forage quality and indirect effects of forage legumes on soil quality. The review culminates in a realistic perspective of forages in current and future agricultural systems of the Mediterranean region.

\section{Mediterranean forage legumes}

As the centre of origin for many forage legumes, the Mediterranean region is a major resource of biodiversity and contains an estimated 24000 species of plant flora (Mathison, 1983; Greuter, 1991). The number of pasture and forage legumes of the Mediterranean and neighbouring steppe climate zones is large and widespread across the Eastern Mediterranean and Western Asian regions, where they have evolved with distinctive reproductive strategies to withstand the effects of hot summers and long periods of drought (Norman et al., 2005). Filling different niches, a wide range of annual and perennial forage legumes are currently grown under the diverse environmental conditions of the Mediterranean region in farming systems primarily dominated by small ruminants (Porqueddu and Sulas, 1998).

Of the diverse forage legume species adapted to the Mediterranean climate, vetches (Vicia spp.), chicklings (Lathyrus spp.), annual medics (Medicago spp), clovers (Trifolium spp.) and species of the Lupinus, Lotus, Onobrychis, Hedysarum and Ornithopus genera are considered to be the most agronomically important and economically valuable species for the WANA region (Mathison, 1983; Polhill and van der Maesen, 1985; Robertson and Bounejmate, 1999). Although underutilized, there is a growing interest in some of the perennial legumes, such as sulla (Hedysarum coronarium) and serradella (Ornithopus compressus) (Robertson and Bounejmate, 1999; Sulas, 2005). The most commonly cultivated forage legumes with immediate agricultural potential for the Mediterranean region are presented in Table 1.

Historically, the cultivation of forage legumes can be traced back to 1000-1500 BC when alfalfa 
Table I Most commonly cultivated forage legumes in the Mediterranean region.

\begin{tabular}{ll}
\hline \multicolumn{1}{c}{ Genera } & \multicolumn{1}{c}{ Species } \\
\hline Vicia & V. ervilia, V. hybrid, V. narbonensis, V. pannonica, V. villosa, V. sativa subs sativa and sativa subs amphicarpa \\
Lathyrus & L. sativus, L. ochrus and L cicera \\
Medicago & M. intertexta, M. laciniata, M. littoralis, M. polymorpha, M. rigidula, M. rotata, M. scutellata, M orbicularis, M. truncatula \\
& and M. sativa \\
Trifolium & T. alexandrinum, T. resupinatum, T. cheleri, T. subterraneum, T. campestre T. angustifolium T. fragiferum, T. repens and \\
Lotus & T. pratense \\
Onobrychis & L. corniculatus, L. glaber and L. pedunculatus. \\
Hedysarum & H. coronorium \\
Lupinus & L. albus, L. angustifolius and L. luteus \\
Ornithopus & O. sativa and $O$. compressus \\
\hline
\end{tabular}

(Medicago sativa) was grown in Anatolia (modern Turkey). Currently, the total cultivated area dedicated to fodder production is low, and there is widespread feed shortage, but forage legumes are still important in the WANA region and play a pivotal role in the following crop-livestock farming systems (Buddenhagen, 1990):

1 Perennial forage legumes that are primarily utilized for hay or silage with little grazing, such as alfalfa, sainfoin and sulla.

2 Annual legumes, such as vetches, grasspea and berseem clover, that are sown and harvested within a single growing season.

3 Self-reseeding annual legumes, such as annual medics and subterranean clover, or perennial legumes, such as alfalfa and sainfoin, which are cultivated in rotation with cereal crops.

4 Pasture legumes that are overseeded into natural rangelands with the intent of increasing pasture and animal productivity. Although common in many parts of the world, permanent sown pastures are not a traditional practice in the WANA region.

For the past 3-4 decades, ICARDA has paid particular attention to annual feed-legume species such as Vicia spp. and Lathyrus spp. for use in dry areas where rainfall is between 250 and $350 \mathrm{~mm}$. These areas are found between the steppe and high-potential cerealgrowing regions in WANA, have a very fragile agroecosystem and are currently threatened by further degradation and erosion because of the increasing annual cropping of barley in response to increasing population pressure (Ghassali et al., 1999; Ryan et al., 2008a; Louhaichi et al., 2012). However, there is an opportunity for the introduction of drought- and/or cold-tolerant annual feed-legume species, such as Vicia spp. and Lathyrus spp., for augmenting feed resources and preventing soil degradation of these regions.

Both Vicia spp. and Lathyrus spp. are recognized for their potential to produce extra feed from fallow lands (El Moneim, 1993a; Jones and Singh, 2000a) and are one of the major options being considered to interrupt barley monoculture or to replace fallow in the fallowbarley rotations. These species are sown and harvested in a single year and can be used for grazing during the winter/early spring period, harvested for hay in spring or harvested for grain and straw at maturity. Despite the huge diversity of Mediterranean legume species, relatively few have been used as feed crops and they have received little attention by agronomists and plant breeders. Three species of Lathyrus and nine of Vicia are potentially important, but few of these have been tested and used. In areas where annual rainfall is $<300 \mathrm{~mm}$, the use of Lathyrus spp. is common, whereas in higher-rainfall areas there are large areas of common vetch (Vicia sativa L.) and bitter vetch (V. ervilia (L.) Willd.) (Table 2).

Although precise estimates of the area of production of these forage legumes are not available, some reports suggest that total areas under Vicia spp. might be more than 600000 ha in six countries of the WANA region (Algeria, Turkey, Cyprus, Iraq, Tunisia and Jordan). Lathyrus sativus L. (grasspea) is common in India and covers $1 \cdot 6-2 \cdot 0$ million ha and is also common in Pakistan, Nepal, Afghanistan, China, Ethiopia, Greece, Portugal and France. Lathyrus cicera L. is found in Cyprus, Greece, Libya, Iran, Iraq, Spain and Syria, while L. ochrus (L.) DG is the main legume species found in Cyprus and Greece.

An important research activity at ICARDA has been to study the use of feed legumes for feed production and to evaluate their potential role in developing sustainable agricultural systems in WANA. The general objective of the breeding programme was to develop and disseminate a range of improved feed-legume crops adapted to various agro-ecological zones and to target these crops to feed livestock in areas receiving average annual rainfall ranging downwards from 400 to $250 \mathrm{~mm}$. It was also thought desirable to have widely adapted cultivars that could be recommended 
Table 2 Adaptation and research of Lathyrus and Vicia spp. in the WANA region.

\begin{tabular}{|c|c|c|c|}
\hline Species & Use & Adaptation (rainfall, mm) & Research \\
\hline Lathyrus sativus & $\mathrm{GZ}, \mathrm{G}, \mathrm{S}$ & $<300$, moderate cold & $\begin{array}{l}\text { Resistance to Orobanche and foliar diseases; high } \\
\text { HI }(\%) \text {; low } \sim \text {-ODAP content. }\end{array}$ \\
\hline Lathyrus cicera & $\mathrm{G}, \mathrm{S}$ & $<300$, moderate cold & $\begin{array}{l}\text { Resistance to Orobanche and foliar diseases; high } \\
\text { HI }(\%) \text {; low -ODAP content }\end{array}$ \\
\hline Vicia sativa ssp. Amphicarpa & GZ & 250, cold, marginal & Improve biomass yield, hard seededness. \\
\hline Vicia sativa & $\mathrm{GZ}, \mathrm{G}, \mathrm{S}, \mathrm{H}$ & $>300$, moderate cold & $\begin{array}{l}\text { Leafiness, non-shattering pods; resistance to foliar } \\
\text { diseases and nematode. }\end{array}$ \\
\hline Vicia narbonensis & $\mathrm{G}, \mathrm{S}$ & $<300$, moderate cold & $\begin{array}{l}\text { Earliness, improve } \mathrm{HI}(\%) \text {, botrytis, downy mildew } \\
\text { resistance, low tannin and GEC content. }\end{array}$ \\
\hline Vicia ervilia & $\mathrm{G}, \mathrm{S}$ & $>300$, cold & Reduce pod shattering. \\
\hline Vicia pannonica & $\mathrm{GZ}, \mathrm{G}, \mathrm{S}$ & $\begin{array}{l}\text { >300, high elevation, } \\
\text { severe cold }\end{array}$ & Improve $\mathrm{HI}(\%)$, ascochyta blight resistance \\
\hline
\end{tabular}

$\mathrm{G}=$ grain; $\mathrm{GZ}=$ grazing; $\mathrm{H}=$ hay; $\mathrm{S}=$ straw $\mathrm{HI}=$ harvest index

for different locations with similar agro-ecological conditions.

In feed-legume improvement, two major genera are dealt with: Vicia and Lathyrus. Within these genera, several species have been assessed. These species represent a wide range of feed-legume crops grown in the low-rainfall areas $(\leq 350 \mathrm{~mm}$ rainfall) and will be evaluated for their utility and fit in various niche environments. Of the vetches, we selected or hybridized genotypes of $V$. sativa $L$. (common vetch), $V$. narbonensis L. (narbon vetch), V. villosa spp. dasycarpa Tan (woolly-pod vetch), V. ervilia L. (bitter vetch), V. palaestina (Palestinian vetch), V. pannonica GR (Hungarian vetch). Similarly, within the chickling species, L. sativus L. (common chickling or grasspea), L. cicera L. (dwarf chickling) and L. ochrus (L.) DG (ochrus vetch) were selected.

\section{Vetches (Vicia spp.)}

In regional testing trials, many breeding lines of Vicia spp. and Lathyrus spp. were evaluated in different locations and years (environments) before the final selection of suitable lines (El Moneim, 1992; El Moneim and Cocks, 1992). Breeding for improved yield was supplemented by improving the quality. Therefore, attributes such as palatability and nutritive value of the herbage, hay, grain and straw were also considered, and feeding trials were carried out. The aim was to serve national breeding programmes through assembling, classifying, maintaining and distributing germplasm; developing and supplying breeding populations with sufficient diversity to be used in different environments; and coordinating international trials to facilitate multi-location testing and identification of widely adapted cultivars. A total of 4267 Vicia accessions were assessed as well as 1315 Lathyrus accessions.
The testing of 25 promising lines in each of $V$. sativa, $V$. ervilia and $V$. villosa ssp. dasycarpa under contrasting rainfall, which varied from 233 to $504 \mathrm{~mm}$, and absolute minimum temperature from $5 \cdot 8-9 \cdot 9^{\circ} \mathrm{C}$, identified considerable variation between species and lines within the same species. Vicia sativa was most affected by frost, whereas $V$. villosa ssp. dasycarpa proved to be cold-tolerant (Table 3). Although V. villosa ssp. dasycarpa produced high herbage yield in the spring, its grain yield

Table 3 Variability in quantitatively scored traits in three (Vicia spp.) species (adapted from El Moneim and Cocks, 1992).

\begin{tabular}{lll}
\hline Species/traits* & Range & Means \pm SE \\
\hline Vicia sativa & & \\
Seedling vigour & $2 \cdot 5-4 \cdot 5$ & $3 \cdot 79 \pm 0 \cdot 30$ \\
Winter growth & $3 \cdot 0-5 \cdot 0$ & $4 \cdot 01 \pm 0 \cdot 40$ \\
Cold effect & $2 \cdot 1-4 \cdot 5$ & $3 \cdot 60 \pm 0 \cdot 31$ \\
Spring growth & $4 \cdot 3-5 \cdot 0$ & $4 \cdot 46 \pm 0 \cdot 37$ \\
Leafiness & $3 \cdot 5-5 \cdot 0$ & $4 \cdot 25 \pm 0 \cdot 40$ \\
Vicia ervilia & & \\
Seedling vigour & $1 \cdot 9-3 \cdot 5$ & $3 \cdot 01 \pm 0 \cdot 30$ \\
Winter growth & $2 \cdot 5-5 \cdot 0$ & $3 \cdot 75 \pm 0 \cdot 46$ \\
Cold effect & $0 \cdot 5-2 \cdot 0$ & $1 \cdot 01 \pm 0 \cdot 10$ \\
Spring growth & $2 \cdot 1-5 \cdot 0$ & $3 \cdot 55 \pm 0 \cdot 30$ \\
Leafiness & $2 \cdot 0-5 \cdot 0$ & $3 \cdot 70 \pm 0 \cdot 28$ \\
Vicia villosa ssp. dasycarpa & & \\
Seedling vigour & $1 \cdot 1-3 \cdot 2$ & $2 \cdot 72 \pm 0 \cdot 20$ \\
Winter growth & $0 \cdot 9-1 \cdot 0$ & $1 \cdot 57 \pm 0 \cdot 13$ \\
Cold effect & $0 \cdot 5-1 \cdot 5$ & $1 \cdot 01 \pm 0 \cdot 09$ \\
Spring growth & $0 \cdot 6-5 \cdot 0$ & $3 \cdot 42 \pm 0 \cdot 26$ \\
Leafiness & $1 \cdot 0-4 \cdot 0$ & $3 \cdot 13 \pm 0 \cdot 30$ \\
\hline
\end{tabular}

*Visual scale basis where $0=$ poor, and $5=$ very good, and for cold effect $0=$ no damage, and $5=$ nearly all plants killed by frost. 
was low, resulting in a low harvest index (HI). Both $V$. ervilia and $V$. sativa produce high grain yield with a high HI.

There were also differences in phenology (Table 4), with $V$. ervilia being the earliest in flowering and maturity, reaching 50\% flowering when the other two species had just commenced. Vicia villosa ssp. dasycarpa flowered 2-3 weeks later than common vetch and bitter vetch and reached maturity after $180 \mathrm{~d}$. The average flowering period was 37, 23 and $45 \mathrm{~d}$ for common vetch, bitter vetch and woolly-pod vetch, respectively. These findings demonstrate the potential of Vicia spp. to replace fallow or to interrupt monoculture barley rotations in the dry areas of WANA.

The great variation in their qualitative and quantitative characters provides an opportunity to select suitable genotypes for cultivation in different niches within the prevailing farming systems. For example, the rapid winter and spring growth of $V$. sativa suggest that it could be grown for early grazing when feed shortages are acute in areas with mild winters. It could also be recommended for haymaking or for straw and grain production (Jones, 2000). Vetch is widely used in a mixture with oat (VicialAvena sativa L.) in Tunisia (Halila et al., 1990). This forage mixture is as profitable as other cash crops, especially during dry years when there is a severe shortage in animal feed. It can be more expensive than the subsidized grain prices in some WANA countries, especially during years of drought.

In areas where winters are severe and cold and frost occurrence is frequent, $V$. pannonica, $V$. villosa ssp. dasycarpa and $V$. ervilia are the most suitable vetch species because of their high degree of cold tolerance (Ratinam et al., 1994). Keatinge et al. (1991) indicated that woolly-pod vetch 'Selection 683' could survive the extreme conditions of frost and be a productive forage crop in the Baluchistan highlands of West Asia. Variation in phenology can also affect the utilization of any species by farmers (El Moneim, 1992). As feedlegume species can be used for grazing, hay, straw and grain production, consideration of the phenology of the various species can easily identify the utilization of a particular species and hence its suitability for the farming system.

For example, the early flowering and maturing cultivars of $V$. ervilia with high grain and straw yields suggest that these could be used by farmers who require straw and grain for summer feeding. Because of its leafiness and relatively high HI, $V$. sativa could be used for hay making or straw and grain production. Vicia villosa ssp. dasycarpa is most suitable for grazing because of its long flowering period, high herbage production and low HI. Vicia hybrida L. and V. palaestina are also suitable for grazing because of their long flowering period and prostrate growth habit.

Both $\mathrm{HI}$ and grain yield are likely to determine the way in which farmers use feed legumes. Crops such as narbon vetch ( $V$. narbonensis) with high grain yield and high HI (Table 5) could be used as a dual-purpose crop for grain and straw production. Its upright growth habit enables easier mechanical harvesting (El Moneim, 1993a). The lines with high HI also have potential to give high biological yield. Narbon vetch possesses high seedling vigour with rapid winter growth and negligible cold damage. In studies, grain yield varied from 0.5 to $1.9 \mathrm{t} \mathrm{ha}^{-1}$ with $\mathrm{HI}$ varying from 30 to $40 \%$; below $300 \mathrm{~mm}$ rainfall, the grain yield varied from $0.5 \mathrm{t} \mathrm{ha}^{-1}$ when rainfall was $195 \mathrm{~mm}$ to $1.4 \mathrm{t} \mathrm{ha}^{-1}$ when rainfall was $245 \mathrm{~mm}$.

Most of the lines had wide adaptation to dry areas in terms of both grain yield and stability. This combination makes narbon vetch a valuable species for dry areas. Because of their susceptibility to the parasitic broomrape (Orobanche crenata Frosk), the late-maturing lines of $V$. sativa produced low seed yield and had low HI. The early lines were also susceptible but were able to set seeds before the worst effects of broomrape occurred. In contrast, V. villosa ssp. dasycarpa is resistant to broomrape (Linke et al., 1993), but still produces low seed yields. It is recommended for areas heavily infested with broomrape.

Losses of seeds from matured pods (pod shattering) are common in $V$. sativa. This feature of pod shattering restricts its use as a leguminous forage crop to replace the fallow period in fallow-cereal rotations (El

Table 4 Range of variability in phenological traits of three Vicia spp (adapted from El Moneim and Cocks, 1992).

\begin{tabular}{|c|c|c|c|c|c|c|}
\hline \multirow[b]{2}{*}{ Trait* } & \multicolumn{2}{|c|}{ V. sativa } & \multicolumn{2}{|c|}{ V. ervillia } & \multicolumn{2}{|c|}{ V. villosa ssp. dasycarpa } \\
\hline & Range & Mean \pm SE & Range & Mean \pm SE & Range & Mean \pm SE \\
\hline \multicolumn{7}{|l|}{ Days to: } \\
\hline Start of flowering & $105-115$ & $110 \pm 1.03$ & $95-109$ & $102 \pm 1.02$ & $114-136$ & $120 \pm 1 \cdot 10$ \\
\hline $50 \%$ flowering & $122-133$ & $127 \pm 1.09$ & $105-114$ & $112 \pm 1 \cdot 04$ & $120-160$ & $140 \pm 1 \cdot 17$ \\
\hline $100 \%$ flowering & $134-160$ & $147 \pm 1 \cdot 10$ & $115-130$ & $125 \pm 0.95$ & $140-168$ & $165 \pm 1 \cdot 20$ \\
\hline Full maturity & $170-189$ & $160 \pm 1 \cdot 18$ & $122-140$ & $131 \pm 1.09$ & $162-196$ & $180 \pm 1 \cdot 28$ \\
\hline
\end{tabular}

* Measured as number of days from germination. 
Table 5 Mean grain yield and harvest index of Narbon vetch for eight environments and their ranks (adapted from El Moneim, 1993a).

\begin{tabular}{|c|c|c|c|c|c|c|}
\hline \multicolumn{3}{|c|}{ Environments } & \multirow[b]{2}{*}{ Grain yield (t ha $\left.{ }^{-1}\right)$} & \multirow[b]{2}{*}{ Rank } & \multirow[b]{2}{*}{ Harvest index (\%) } & \multirow[b]{2}{*}{ Rank } \\
\hline Sites & Years & Rainfall (mm) & & & & \\
\hline Tel Hadya & 1985-1986 & 316 & 1.55 & 3 & 38 & 2 \\
\hline Tel Hadya & 1986-1987 & 358 & 1.90 & 1 & 40 & 1 \\
\hline Tel Hadya & $1987-1988$ & 504 & $1 \cdot 10$ & 6 & 34 & 6 \\
\hline Tel Hadya & 1988-1989 & 233 & 0.90 & 7 & 32 & 7 \\
\hline Breda & 1985-1986 & 218 & $1 \cdot 29$ & 5 & 36 & 4 \\
\hline Breda & $1986-1987$ & 245 & $1 \cdot 40$ & 4 & 36 & 4 \\
\hline Breda & $1987-1988$ & 415 & $1 \cdot 61$ & 2 & 38 & 3 \\
\hline Breda & 1988-1989 & 195 & 0.47 & 8 & 30 & 8 \\
\hline Mean & & & $1 \cdot 28$ & & 35 & \\
\hline LSD $(0.05)$ & & & 0.54 & & 4 & \\
\hline
\end{tabular}

Moneim, 1993b). Non-shattering traits were incorporated into agronomically promising lines. Lines having 95-97\% non-shattering pods were obtained, as compared to $40-45 \%$ in the original cultivated lines. The practical potential of developing non-shattering lines was an increase in grain yield, thus reducing the price of seed and allowing farmers to increase the area cultivated with common vetch and, in turn, to increase livestock production. Operationally, it facilitates mechanical harvesting and allows farmers to defer vetch harvesting until they finish the lentil harvest, which otherwise would coincide with the common vetch harvest and would invariably be delayed in preference to the feed-legume crop. In contrast to the annual medics, the soft seededness of vetch is one of the most important attributes to facilitate the use of herbicides to kill vetch weeds that germinate in any subsequent cereal crop.

\section{Growth habit of underground vetch}

Underground vetch is a Mediterranean species found in western Asia and southern Africa. During the evaluation of new germplasm of Vicia spp., a few genotypes of $V$. sativa ssp. amphicarpa were discovered. The word 'amphicarpa' means producing two kinds of fruits: the plants not only flower aboveground but also flower underground by producing cleistogamous flowers that are never exposed to the light. Unlike subclover, the underground pods are protected from overgrazing at all times. Underground vetch is native to Mediterranean grasslands and confined to poor soils and rocky slopes and is best adapted to microhabitats that are relatively too dry for other vetches. Its natural distribution includes most grassland areas receiving $<300 \mathrm{~mm}$ rainfall in south-east Turkey, the central Anatolian region and northern Syria. The possibility of using underground vetch as a self-reseeding annual feed legume in certain pastures and rangelands is intriguing. Its ability to produce both aerial and underground seeds should enhance drought resistance and persistence under heavy grazing.

Two species, Vicia sativa ssp. amphicarpa Dorth (underground vetch) and L. ciliolatus L. (underground chickling), are characterized by producing both underground and aboveground pods. Two approaches are used to develop feed-legume crops: (i) selection from wild types to develop cultivated types and (ii) genetic improvement by hybridization. The process of developing new cultivar types from wild species (Robertson et al., 1996) involves the preliminary evaluation of germplasm for the desired characteristics; progeny testing for the selected genotypes; evaluation of the selected genotypes in micro-plot field trials, followed by evaluation of the promising selections in advanced yield trials in at least two contrasting sites, such as at Tel Hadya $(330 \mathrm{~mm}$ year $^{-1}$ ) and Breda (280 $\mathrm{mm} \mathrm{year}^{-1}$ ); and lastly the multi-location testing of promising lines in different agro-ecological zones.

Observations on underground vetch (V. amphicarpa Dorth) revealed that drier conditions favoured earlier subterranean flowering. Consequently, the proportion of subterranean pods was higher. Clipping of aerial shoots stimulated basal branching both above- and belowground, decreased the total number of fruits and increased the percentage of subterranean flowers. Under heavy clipping, the populations were maintained by the presence of underground pods. During the 1989/90 growing season, underground vetch was grown in large plots $\left(100 \mathrm{~m}^{2}\right)$ replicated three times and allowed to be grazed by sheep at the end of each month: February, March and April. Plots were also left without grazing, along with barley plots. The produc- 
tivity of the vetch was determined, and the amount of underground seeds under each grazing treatments was estimated. During the 1990/91 season, barley (Hordeum vulgare) cv. Atlas 46 was planted after underground vetch on the same plots and also after the barley plots of $1989 / 90$. During the barley phase, the seed bank of underground vetch was monitored (Table 6).

Barley grown after barley produced significantly less yield, both in terms of grain as well as straw, than barley grown after underground vetch. Grazing of underground vetch had no effect on the productivity of barley grown after the vetch. Early grazing of vetch greatly affected the yield of underground seeds. The difference in vetch seeds found buried in the soil at the beginning and at the end of the barley phase provided an indication of the germination and hard seededness of the buried vetch seed during the barley phase. The self-reseeding nature of the underground vetch indicated that it could play an important role in drier areas as a self-reseeding pasture plant.

One of the most important advantages is that underground vetch is naturally adapted to a moderate level of disturbance, which makes it an ideal candidate for ley-farming systems and may be better adapted by virtue of its large underground seeds to deep ploughing, a common feature in WANA. In this matter, it differs from most other legumes, such as annual medics (Medicago spp.), which occur naturally in undisturbed habitats. While much effort has been expended in developing medic technology, adoption has been poor due to on-farm constraints such as grazing management and poor harvesting (Christiansen et al., 2000b). In the past 2-3 decades, emphasis was given by ICARDA to these legume species. A breeding programme was initiated in 1985 and promising lines were identified and tested under different environments (Table 7).

Table 6 Herbage yield of Vicia sativa ssp. amphicarpa in the establishment year 1988/89, under three grazing treatments (adapted from Christiansen et al., 1996).

\begin{tabular}{|c|c|c|c|c|c|c|c|}
\hline \multirow[b]{2}{*}{ Yields* } & \multicolumn{4}{|c|}{ Underground vetch grazed $\left(\mathrm{kg} \mathrm{ha}^{-1}\right)$} & \multirow[b]{2}{*}{ Barley } & \multirow[b]{2}{*}{$\pm \mathbf{S E}$} & \multirow[b]{2}{*}{ LSD $(P<0.05)$} \\
\hline & February & March & April & No grazing & & & \\
\hline Herbage yield (establishment year) & 830 & 730 & 860 & 2020 & - & 57 & 140 \\
\hline Grain yield of barley & 1966 & 2035 & 1925 & 1909 & 1599 & 98 & 227 \\
\hline Total barley biomass & 4346 & 4193 & 3947 & 3877 & 3143 & 215 & 497 \\
\hline \multicolumn{8}{|l|}{ Seed bank barley phase, 1990, 1991} \\
\hline Start & 50 & 130 & 160 & 240 & - & 27 & 75 \\
\hline End & 32 & 95 & 141 & 218 & - & 34 & 85 \\
\hline Herbage, vetch 1991/1992 & 3258 & 3879 & 3708 & 3900 & - & 320 & 590 \\
\hline
\end{tabular}

*Barley yield grown after underground vetch in comparison with barley after barley, seed banks at the beginning and end of the barley phase on 1990/91 and herbage production of self-regenerated underground vetch in 1991/92.

Table 7 Mean herbage and seed yields for eight environments (ICARDA 1985-1989).

\begin{tabular}{|c|c|c|c|c|c|c|}
\hline \multicolumn{3}{|c|}{ Environments } & \multicolumn{2}{|c|}{ Herbage } & \multicolumn{2}{|c|}{ Seed } \\
\hline Sites & Rainfall & Year & Yield & Rank & Yield & Rank \\
\hline $\mathrm{mm}$ & & & $\mathrm{kg} \mathrm{ha}^{-1}$ & & & \\
\hline Tel Hadya & 361 & $1985 / 86$ & 2676 & 3 & 846 & 4 \\
\hline Tel Hadya & 358 & $1986 / 87$ & 2809 & 2 & 1358 & 1 \\
\hline Tel Hadya & 504 & $1987 / 88$ & 2579 & 4 & 912 & 3 \\
\hline Tel Hadya & 233 & $1988 / 89$ & 1980 & 5 & 497 & 6 \\
\hline Breda & 218 & $1985 / 86$ & 1222 & 8 & 373 & 8 \\
\hline Breda & 245 & $1986 / 87$ & 1332 & 7 & 392 & 7 \\
\hline Breda & 415 & $1987 / 88$ & 3282 & 1 & 1250 & 2 \\
\hline Breda & 195 & $1988 / 89$ & 1465 & 6 & 547 & 5 \\
\hline Mean & & & 2418 & & 772 & \\
\hline $\operatorname{LSD}(0 \cdot 05)$ & & & 623 & & 211 & \\
\hline
\end{tabular}




\section{Grain and forage quality of vetches}

In developing highly productive feed legumes, it would be desirable if some attributes could be identified at the morphological level that could prove to be useful selection criteria. Investigations revealed that a high degree of leafiness and leaf retention could improve the palatability and nutritive value of a feed legume. Development of a high-potential feed legume would normally require a multidisciplinary approach involving quantity as well as quality aspects, the latter being of special importance, as they relate to animal performance. Feed-legume crops have little relevance until these traits are evaluated and factors such as digestibility and utilization determined.

Ideally, high yield should be supplemented by high quality. Although woolly-pod vetch is mainly recommended for grazing, the quality of its dry herbage is relatively low in terms of its crude protein (CP) percentage and in vitro dry matter disappearance (Table 8 ). This is due to a high proportion of leaf drop, the leaf/stem ratio and a rapid accumulation of nondigestible fibres which contribute to its high dry matter content (El Moneim et al., 1990). The CP content of the grain and straw of narbon vetch varied from 26 to $32 \%$ and from 6.4 to $12 \%$, respectively. The CP $\%$ of the straw of narbon vetch is greater than that of wheat, barley, lentil and woolly-pod vetch (Rees et al., 1991). Genotypic differences in the quality aspects of other feed-legume species were reported by El Moneim et al. (1990). The protein content found in the grain and straw of narbon vetch emphasized the potential of this crop as a source of supplementary animal feed in dry areas. This attribute, and its adaptability to drier areas $(<300 \mathrm{~mm}$ rainfall), illustrated its potential for use in the drier areas, especially in areas receiving rainfall between 250 and $300 \mathrm{~mm}$ where other legumes do not perform well. More research is needed on the nutritional values of the grain and straw as they are known to carry antinutritional or antipalatability factors.

Recent on-farm studies at ICARDA have focused on the identification of Vicia sativa L., Vicia narbonensis L. and L. sativus L. accessions with suitable adaptation and quality herbage yield for specific environments. In these on-farm studies, reported by Larbi et al. (2010a,b), intraspecies and interspecies differences in herbage $\mathrm{CP}$, acid detergent fibre (ADF), neutral detergent fibre (NDF) and in vitro organic matter digestibility (IVOMD) in $V$. sativa and L. sativus, were compared in both dry $(140 \mathrm{~mm})$ and wet $(283 \mathrm{~mm})$ environments. Vivia sativa had higher $(P<0.05)$ grain and straw production than the L. sativus, but for L. sativus, the CP and IVOMD of the straw were higher $(P<0.05)$ than those of the V. sativus, Lathyrus accession 445, and V. narbonensis accessions 2561 and 2380, indicating they had potential for quality herbage production.

\section{Chicklings (Lathyrus spp.)}

Chicklings (Lathyrus spp.) are feed legumes with high yield potential in the Mediterranean region, especially in areas where the annual rainfall is $<300 \mathrm{~mm}$ (El Moneim and Cocks, 1992). Three species of Lathyrus are potentially important: L. sativus (common chickling or grasspea), L. cicera (dwarf chickling) and L. ochrus (ochrus vetch). L. sativus is a drought-tolerant feed and food legume. L. cicera L., because of its ability to tolerate drought and produce good yields under adverse conditions, is one of the major components of human diets in times of drought-induced famine. Grasspea has also been tested in Canadian prairies, where it had potential valuable for feeding livestock (Briggs et al., 1983; McCartney and Fraser, 2010). Lathryus ochrus is susceptible to frost, and when rainfall is below $300 \mathrm{~mm}$, its grain yield decreases. It is resistant to broomrape. For these reasons, Lathyrus was recommended only for regions of mild winters such as Western Australia and southern Australia. L. sativus and L. cicera produce high grain and straw yields when rainfall is below $300 \mathrm{~mm}$, and they are recommended for grain and straw production in drier areas. They are also moderately cold-tolerant.

In ICARDA's programme, a total of 25 elite lines each of L. sativus and L. cicera were tested at two sites, Tel Hadya and Breda, Syria. L. sativus had higher

\begin{tabular}{lccc}
\hline \multicolumn{1}{c}{ Character } & $\begin{array}{c}\text { V. sativa } \\
\text { Means } \pm \text { SE }\end{array}$ & $\begin{array}{c}\text { V. ervillia } \\
\text { Mean } \pm \text { SE }\end{array}$ & $\begin{array}{c}\text { V. villosa ssp. } \\
\text { dasycarpa Mean } \pm \text { SE }\end{array}$ \\
\hline $\begin{array}{l}\text { Crude protein, \% } \\
\text { In vitro dry matter } \\
\text { digestibility,\% }\end{array}$ & $19 \cdot 5 \pm 2 \cdot 1$ & $21 \cdot 5 \pm 2 \cdot 3$ & $16 \cdot 5 \pm 1 \cdot 8$ \\
$\begin{array}{l}\text { Neutral detergent } \\
\text { fibre, g kg-1 }\end{array}$ & $69 \cdot 0 \pm 5 \cdot 9$ & $72 \cdot 0 \pm 6 \cdot 3$ & $46 \cdot 0 \pm 5 \cdot 8$ \\
Acid detergent fibre, $\mathrm{g} \mathrm{kg}^{-1}$ & $220 \pm 19$ & $200 \pm 19$ & $400 \pm 31$ \\
\hline
\end{tabular}

Table 8 Quality characteristics in three Vicia spp. (adapted from El Moneim et al., 1990b). 
Table 9 Mean herbage and grain yields ( $\mathrm{t} \mathrm{ha}^{-1}$ ) of 25 entries of Lathyrus sativus and Lathyrus cicera in advanced yield trials at Tel Hadya and Breda, Syria (1999/2000) (adapted from El Moneim and Cocks, 1992).

\begin{tabular}{|c|c|c|c|c|}
\hline \multirow{2}{*}{ Species } & \multicolumn{2}{|c|}{ Herbage yield $\left(\mathrm{t} \mathrm{ha}{ }^{-1}\right)$} & \multicolumn{2}{|c|}{ Grain yield $\left(\mathrm{t} \mathrm{ha} \mathrm{a}^{-1}\right)$} \\
\hline & Tel Hadya & Breda & Tel Hadya & Breda \\
\hline L. sativus Mean $\pm \mathrm{SE}$ & $4 \cdot 4 \pm 0 \cdot 17$ & $1 \cdot 9 \pm 0 \cdot 17$ & $0.95 \pm 0.1$ & $0.8 \pm 0.09$ \\
\hline L. cicera Mean $\pm \mathrm{SE}$ & $4 \cdot 2 \pm 0 \cdot 3$ & $1 \cdot 7 \pm 0 \cdot 16$ & $1 \cdot 2 \pm 0 \cdot 12$ & $0.9 \pm 0.06$ \\
\hline
\end{tabular}

herbage yield than L. cicera at Tel Hadya, whereas L. cicera produced the highest grain yield at both locations. Great variability was also reported between species and lines within the same species. The earlymaturity lines of L. sativus and L. cicera and the high grain and herbage yields reported were due to the rapid winter growth during the mild winter 2000 (Table 9).

\section{Grain and forage quality of chicklings}

Improved forage quality is an important objective in the breeding programme for Lathyrus spp. The nutritive-value component of the forage breeding programme revealed that there was great variation in the forage quality characteristics such as CP and organic matter digestibility (DOMD) concentrations and in the tannin content of the Lathyrus elite lines (Table 10). Overall, hay and straw of L. sativus were higher in both CP content and DOMD, compared with that of L. cicera. The high CP content found in the hay and straw was attributed to a high leaf/stem ratio and to high leaf retention.

One of the main objectives of ICARDA's grainlegume breeding programme is the identification of nutritious crops that are capable of providing good consistent yields under adverse conditions. One of the drawbacks of $L$. sativus is that excessive use in the diet of humans and domesticated animals causes 'lathyrism', a nervous disorder resulting in incurable paralysis of the lower limbs (Briggs et al., 1983). The occurrence of lathyrism in human and domestic animals is caused by the presence of a neurotoxin compound, a free amino acid known as 3-N-Oxalyl-L-2, 3 diaminopropionic acid ( -ODAP). Lathyrus is of special interest because of its ability to tolerate drought, and the screening of germplasm for low -ODAP is considered worthwhile (Aletor et al., 1994a,b). The chemical estimation of -ODAP levels is quite laborious and expensive, thus limiting its use in the screening and identification of lines that are low in neurotoxin. Nevertheless, a programme of tackling the issue of toxicity has started.

In 1988/89, promising breeding lines of L. sativus, L. cicera and L. ochrus were screened for low -ODAP content in seeds using a near-infrared method. Some lines were found to contain low amounts of -ODAP. The identification of lines having low or no detectable $\sim$-ODAP and with a high yield potential in the dry areas would provide a safe food source for humans and a feed source for animals and help to alleviate the protein-calorie malnutrition found in such regions that are generally subject to frequent drought events (El Moniem et al., 2010). This would also make the crops more attractive to marginal farmers and provide an important reserve staple in times of drought and impending famine. A recent study threw new light on the problem of lathyrism. Greenhouse and field studies with various grasspea lines of varying toxin levels indicated that zinc had a role in reducing, but not eliminating the level of the toxin in the crop (El Moniem et al., 2010)

Over the past few years, adapted and high-yielding accessions of forage legumes have been tested in relation to intraspecies variations in dryland environments in north-west Syria (Larbi et al., 2010a). In these studies, variations in days to flowering and pod maturity;

Table 10 Mean concentrations of crude protein (CP), neutral detergent fibre (NDF), acid detergent fibre (ADF) and digestible organic matter in total dry matter (DOMD) for hay and straw of Lathyrus sativus and Lathyrus cicera elite lines in advanced yield trials conducted at Tel Hadya, Syria in 1999/2000 (adapted from El Moneim and Cocks, 1992).

\begin{tabular}{|c|c|c|c|c|c|c|c|c|}
\hline \multirow{2}{*}{ Species } & \multicolumn{4}{|c|}{ Hay } & \multicolumn{4}{|c|}{ Straw } \\
\hline & СР\% & NDF $\mathrm{g} \mathrm{kg}^{-1}$ & ADF $\mathrm{g} \mathrm{kg}^{-1}$ & DOMD\% & СР\% & NDF $\mathrm{g} \mathrm{kg}^{-1}$ & ADF $\mathrm{g} \mathrm{kg}^{-1}$ & DOMD\% \\
\hline L. sativus & $21 \cdot 0 \pm 0.09$ & $320 \pm 1 \cdot 3$ & $180 \pm 0 \cdot 9$ & $75 \cdot 0 \pm 0 \cdot 12$ & $14 \cdot 0 \pm 0 \cdot 07$ & $450 \pm 7 \cdot 8$ & $250 \pm 3 \cdot 7$ & $60 \cdot 0 \pm 0.57$ \\
\hline Mean \pm SE & & & & & & & & \\
\hline $\begin{array}{l}\text { L. cicera } \\
\text { Mean } \pm \mathrm{SE}\end{array}$ & $18 \cdot 0 \pm 0 \cdot 30$ & $240 \pm 3 \cdot 9$ & $13 \cdot 0 \pm 2 \cdot 4$ & $79 \cdot 0 \pm 0 \cdot 29$ & $12 \cdot 0 \pm 0 \cdot 11$ & $460 \pm 5 \cdot 0$ & $260 \pm 2 \cdot 7$ & $55 \cdot 0 \pm 0 \cdot 29$ \\
\hline
\end{tabular}


hay, grain and straw yields; concentrations of $\mathrm{CP}, \mathrm{ADF}$ and NDF in organic matter, and IVOMD in hay and straw; and grain $\mathrm{CP}$ and $-\mathrm{N}$-oxalyl diamino propionic acid (-ODAP) were detected in 25 accessions of $L$. sativus L. grown over five cropping seasons. The results from these trials revealed that yields and quality of hay, grain and straw could be used to identify promising grasspea accessions and that grasspea accessions $528,535,553,559,561$ and 563 had a greater potential for production of hay and grain in the non-tropical dry areas.

\section{Medics}

Results from studies conducted in Australia indicated that both cereal and livestock production could be increased using self-regenerating pasture legumes. This was relevant to the Mediterranean areas using medics in rotation with cereals (Puckridge and French, 1983). Due to environmental and ecological similarities between Australia and WANA, there have been many attempts to introduce medics to the WANA region utilizing the Australian ley system of farming. The initial estimate of land suitable for ley farming was 23 million hectares across nine WANA countries. It was believed that inclusion of medics into the farming system could result in large increases in crop yield and feed supply (Carter, 1978). However, efforts to introduce the ley-farming system into the Mediterranean region, where medics are native species, did not result in widespread adoption by farmers (Nordblom et al., 1994; Christiansen et al., 2000b). The fact that plant material used in the projects was developed under the relatively mild winter temperatures prevailing in southern and Western Australia, resulted in major challenges related to farmer perceptions and poor management of medic pastures (Sultan et al., 2001). Thus, the adaptation of some medic cultivars was unsatisfactory under Mediterranean conditions (Cocks et al., 1989; Zoghlami et al., 1996) (Table 11).

Medic pastures and the effectiveness of the leyfaming system were extensively studied at ICARDA during the period when medics were introduced to the WANA region. In a three-year study at ICARDA, 23 selections of $M$. rigidula and one each of $M$. rotata and $M$. noeana were evaluated for their herbage production and seed yield (El Moneim and Cocks, 1986). The seed bank was also monitored during the establishment phase (year 1), wheat-cultivation phase (year 2), and at the pasture-regeneration phase (year 3). Of the $400-800 \mathrm{~kg} \mathrm{seed} \mathrm{ha}{ }^{-1}$ produced in the first year, an average of $87 \%$ remained in the soil in the spring of the third year. The weight of seed regenerating in the third year varied from 30 to nearly $170 \mathrm{~kg} \mathrm{ha}^{-1}$, and the herbage production,
Table II The number of seedlings of medic species counted on 7 February 1985 and the survival of seven medics in Syria on 12 March 1985 (adapted from Cocks et al., 1989).

\begin{tabular}{lcl}
\hline \multicolumn{1}{c}{$\begin{array}{c}\text { Medicago spp. and } \\
\text { genotype }\end{array}$} & $\begin{array}{c}\text { Establishment } \\
\text { (seedlings } \mathbf{~ m}^{-\mathbf{2}} \text { ) }\end{array}$ & $\begin{array}{c}\text { Frost } \\
\text { survival (\%) }\end{array}$ \\
\hline M. scutellata 'Robinson' & 232 & $5 \mathrm{c}$ \\
M. truncatula 'Cyprus' & 536 & $7 \mathrm{de}$ \\
M. truncatula 'Jemalong' & 432 & $14 \mathrm{~cd}$ \\
M. polymorpha 'Circle Valley' & 856 & $21 \mathrm{c}$ \\
M. rotata 'selection 2123' & 1144 & $90 \mathrm{~b}$ \\
M. rigidula 'selection 716' & 816 & $95 \mathrm{ab}$ \\
M. rigidula 'selection 1919' & 864 & $98 \mathrm{a}$ \\
\hline
\end{tabular}

Survival percentages followed by the same letter are not significantly different.

especially in winter, depended heavily on the number of regenerating seedlings. The most productive regenerating pastures produced nearly $2 \mathrm{t} \mathrm{ha}^{-1}$ of dried herbage by lst January, and more than $6 \mathrm{tha}^{-1}$ over the entire growing season (El Moneim and Cocks, 1986). In these studies, the increased wheat production highlighted the potential impact of using medic in rotations with cereals, as the wheat yield following a medic pasture was higher than after other non-legume crops (Cocks et al., 1989) (Table 12).

The experience gained from introducing medic pastures and ley-farming systems in the WANA region indicated that the adoption of medic pastures was poor due to the social, economic and technological constraints. Overall, no farmers independently adopted a medic-wheat rotation. Thus, the incorporation of annual forage legumes into arable rotations, particularly the use of species of Vicia and Lathyrus for early grazing followed by harvesting for hay, silage, or grain and straw was a better alternative than medic pastures under WANA conditions (Oram and de Haan, 1995).

\section{Impacts of forage legumes on soil quality}

Replacement of the fallow phase or interruption of barley monoculture in rotations by well-adapted legumes reduces the hazard of soil erosion by providing protective ground cover during critical periods and improving soil organic matter and therefore soil aggregates (Masri and Ryan, 2006). Compared with cerealcereal rotation, a cereal crop in a cereal-legume rotation develops a deeper root system because of better soil physical conditions, and thus, it is better able to exploit soil water and nutrients within the soil profile. These observations on the positive effects of legumes on soil organic matter and related soil physical and chemical properties were borne out in 
Table 12 Wheat yields $\left(\mathrm{t} \mathrm{ha}^{-1}\right)$ following the first year and regenerating medic compared with wheat yields in traditional rotations with non-legume crops (adapted from Cocks et al., 1989).

\begin{tabular}{|c|c|c|c|c|}
\hline \multirow[b]{2}{*}{ Year } & \multicolumn{2}{|c|}{ First year } & \multicolumn{2}{|c|}{ Regenerating } \\
\hline & Medic pasture & Non-legume crop & Medic pasture & Non-legume crop \\
\hline $1985-86$ & $1 \cdot 29$ & $1 \cdot 24$ & NA & NA \\
\hline $1986-87$ & $1 \cdot 40 a$ & $1 \cdot 08 \mathrm{~b}$ & NA & NA \\
\hline $1987-88$ & 1.95 & 1.64 & $2 \cdot 67 a$ & $1 \cdot 77 \mathrm{~b}$ \\
\hline
\end{tabular}

Different letters for the means of wheat production are significantly different.

ICARDA's long-term trials with both wheat and barley (Ryan et al., 2008a). Mean organic matter levels were higher in the vetch and medic rotations compared with fallow, continuous cropping and with inclusion of food legumes in the rotation (Ryan et al., 2008b) with labile forms consistently higher throughout the year (Ryan et al., 2009a). Similarly, total and mineral nitrogen levels were higher with these forages in the rotation (Ryan et al., 2008c) as was the mineralization potential (Ryan et al., 2003).

The key soil fertility factor constraining productivity and water-use efficiency of the cropping systems in the dry areas of WANA is the limited $N$ inputs to the production system (Ryan et al., 2009b). The average use of fertilizer $\mathrm{N}$ in major agricultural countries of Africa (Algeria, Ethiopia, Libya, Sudan and Tunisia) and Asia (Afghanistan, Syria, and Yemen) that lie within the WANA region, for arable lands and permanent crops, does not exceed $20 \mathrm{~kg} \mathrm{ha}{ }^{-1}$. The major share of this $\mathrm{N}$ use should be applied to permanent crops and crops grown under assured moisture supply. Hence, the $\mathrm{N}$ cycle of the drier areas has its major input from symbiotic $\mathrm{N}_{2}$ fixation. It is here that the food and feed legumes have their major role in ensuring sustained productivity of rainfed farming systems.

Studies using the $\mathrm{N}^{15}$ technique at ICARDA and elsewhere in the region have demonstrated that under optimum management, well-adapted legume species yield $60-120 \mathrm{~kg} \mathrm{~N} \mathrm{ha}^{-1}$ by symbiotic $\mathrm{N}_{2}$ fixation, under conditions where seasonal precipitation is greater than 300 mm (Ryan, 1997; Ryan et al., 2009b). Rotational trials at ICARDA and elsewhere in the region have confirmed that the total $\mathrm{N}$ yield is higher in 'cereal-legume' rotation that in 'cereal-cereal' or 'cereal-fallow' rotations (Ryan et al., 2009b). Rough $\mathrm{N}$-balance studies at ICARDA with food legumes have shown that if harvested only for the grain, most leave a positive soil $\mathrm{N}$ balance, but when harvested for both grain and straw, the balance was invariably negative or near zero. This latter fact notwithstanding, the total influx of $\mathrm{N}$ in the system is higher with legumes incorporated in the rotations compared with cereal-fallow rotation, and considerable soil $\mathrm{N}$ savings are achieved compared with continuous cereal (Harris, 1995).
Research on appropriate combinations of Rhizobium strain $\times$ legume genotype, use of $\mathrm{P}$ fertilizer either in the cereal phase or applied directly to the legume on P-deficient soils (Materon and Ryan, 1995), appropriate adjustment of sowing dates, and control of cyst and root-knot nematodes, Orobanche and Sitona-larvae damage to root nodules has shown promise of improving the symbiotic $\mathrm{N}_{2}$ fixation as well as the fraction of total plant- $\mathrm{N}$ derived from fixation (El Moneim and Bellar, 1993). Studies were initiated at ICARDA and in the region that would permit quantification of $\mathrm{N}$ conservation because of incorporation of legumes in the cereal-based cropping systems. This may permit assessment of the ' $\mathrm{N}$ ' component of the legume effect in rotations.

\section{Forage legumes in cereal-based rotations: diseases and pests}

It is now recognized that forage legumes play a major role in improving subsequent cereal yields by acting as a break crop to cereal-to-cereal root diseases, while also maintaining soil fertility. Forage legume and cereal crops are complementary when it comes to croprotation choices. These attributes have underpinned the practice of crop rotations in the Middle East region, as amply demonstrated by long-term research at ICARDA (Ryan et al., 2008a). Legumes play a vital role in controlling major cereal root diseases, particularly cereal eelworm or cereal cyst nematodes, Heterodera avenae. The combination of high soil $\mathrm{N}$ and reduced nematodes population is cumulative and can result in a big increase in subsequent cereal yield. Vicia spp. and Lathyrus spp. can be used as clearing crops. The nematodes will not reproduce on these plants. Such legumes are profitable for nematode control because grassy-weed control is obligatory for good yields. Medics are less reliable as cleaning phases, not because of the plants themselves but because of the lack of reliability of getting a dense self-sown stand due to problems such as lack of rain, poor seed reserves and Sitona weevil (Alan, 1979) and thus allow grass establishment and consequently some nematode reproduction. 
The intensification of rainfed agriculture by replacement of the 'fallow-cereal' rotation by a 'continuous cereal' system has several undesirable consequences in terms of the build-up of noxious weeds, pests and pathogens, and the accumulation of allelopathic compounds. In addition, the cereal cyst nematode (H. avenae), soil-inhabiting fungi such as Cochlibolus sativus syn., Helminthosporium sativum, the 'take-all disease' pathogen (Gaeumannomyces gramines var. tritici), and the wheat ground beetle (Zabrus tenebroides) can all cause considerable yield decline under continuous cereal-cropping systems. As a break crop, legumes can reduce the cereal yield decline by suppressing the build-up of these pests and pathogens by preventing the build-up of allelopathic compounds.

\section{Future role of forage legumes}

As with any area of scientific endeavour, progress depends upon a gradual accretion of knowledge. This is particularly true where a diversity of aspects have to be seen in an integrated whole. In that respect, the forage research at ICARDA has been fruitful. The work on vetches ranged from their role in cropping systems (Jones and Singh, 2000a,b), hard seededness (Christiansen et al., 1996), disease (Ahmed et al., 2000), and nematode (El Moneim and Bellar, 1993) resistance, effects on soil quality in terms of organic carbon and associated improvements in physical properties (Ryan, 1998; Ryan et al., 2002, 2008b), enhancement of soil $\mathrm{N}$ (Ryan et al., 2008c), improvements in nutritional quality of the grain with respect to $\mathrm{N}$ and protein (Ryan et al., 2008d), and on-farm testing (Thompson et al., 1992; Christiansen et al., 2000a; Larbi et al., 2010a,b). In essence, a coherent picture of all relevant aspects of forages has emerged, with the pathway for future research being more clearly illuminated.

With the adoption of common vetch now increasing at the farm level, the prospects for the crop contributing to animal feed supplies in the Mediterranean zone are bright. However, Jones (2000) expressed caution about vetch adoptions with conservation tillage in relatively drier areas. While the role of forage legumes in relation to animal feed supplies and ancillary benefits in terms of soil quality are now well established, the future challenge is to promote forage-based systems at the farm level. Despite the focus on ley farming with medics and its benefit for soil $\mathrm{N}$, the technology has not met farmers' acceptance and its emphasis has now been reduced, although such legumes have a function in native dryland pastures. This underlines the fact that whatever benefits to science that any technology may exhibit, the efforts in that direction have to be dropped if there is no farmer acceptance.
While the work with underground vetch provides a basis for its use in degraded soils in harsh dry environments, providing a forage source for grazing and at the same two protecting the soil from erosion forces (El Moneim, 1992), major efforts are needed to translate the unique feature of these forages into widespread practice at the farm level. The work on another forage, Lathyrus, raises other tantalizing aspects that go beyond just being an animal feed source. While Lathyrus is a durable forage crop, its seeds are eaten when other foods are scarce. Breeding for reducing the B-ODAP toxin has made considerable strides and will continue to be a research focus (El Moniem et al., 2010). Clearly, this is an agronomic area that has to be pursued not only by agronomists and breeders, but by those from other disciplines such as nutritionists and members of the medical profession.

While relatively few forage species, such as vetch, have received a disproportionate amount of research in the past, the future holds prospects for collaboration with botanists, taxonomists and other plant scientists to explore other lesser-known legume species. In particular, there is scope for the development and evaluation of locally adapted perennial legume species such as $M$. sativa, Onobrychis viciifolia, $H$. coronarium and little-utilized annual legumes, such as $O$. compressus, with higher water-use efficiency and greater tolerance to drought, salinity and grazing.

In summary, forage legumes have had importance historically in the agriculture of the Middle East and will continue to be important, if not more so, given the pressure due to increasing human and animal populations. Forages are a vital source of animal feed in the region's dryland agriculture and can contribute to sustainable use of the land resources.

While many scientific questions need to be answered with respect to the wide array of forages, the focus of future efforts will be on technology adoption with farmers and economic assessment of forage systems. As an international research centre working in collaboration with the region's national agricultural systems, ICARDA needs to reinvigorate its forage programme and meet the region's feed and forage demands of the future.

\section{References}

Ahmed S., Akem C. and El Moneim A.M. (2000) Sources of resistance to downy mildew in narbon (Vicia narbonensis) and common (Vicia sativa) vetches. Genetic Resources and Crop Evolution, 47, 153-156.

Alan D. (1979) Cereal eelworm. South Australia Department of Agriculture, Sheet 9179. Adelaide, South Australia: Department of Agriculture.

Aletor Y.A., El Moneim A.M. and Goodchild A.V. (1994a) Evaluation of the seeds of selected lines of 
three Lathyrus spp. for B-N-Oxalylamino-L-alanine (BOAA) tannins, trypsin inhibitor activity and certain in-vitro characteristics. Journal of the Science of Food and Agriculture, 65, 143-151.

Aletor Y.A., Goodchild A.V. and El Moneim A.M. (1994b) Nutritional and anti-nutritional characteristics of selected Vicia genotypes. Animal Feed Technology, 47, 125-139.

Ates S. and Louhaichi M. (2012) Reflections on agropastoralists in the WANA region: challenges and future priorities. In: Acar Z., Lopez-Francos A. and Porqueddu C. (eds) 14th Meeting of the FAO-CIHEAM Sub network on Mediterranean Pastures and Fodder Crops (New Approaches for Grassland Research in a Context of Climatic and Socio-Economic Changes) Options Méditerranéennes, Series A Mediterranean Seminars No. 102, 511-516.

Aw Hassan A., Shomo F. and Iniguez L. (2010) Trends in small ruminant meat production-consumption gaps in West Asia and North Africa. Implications for intraregional trade. Outlook on Agriculture, 39, 41-47.

B ORLA U G N.E. (2007) Feeding a hungry world. Science, 318, 359.

Briggs C.J., Parenno N. and Campbell E.G. (1983) Phytochemical assessment of Lathyrus species for the neurotoxin agent B-N-Oxalyl-l -a-B-diamino-propionic acid. Journal of Medical Plant Research, 47, 188-190.

BUDDENHAGEN L.W. (1990) Legumes in farming systems in Mediterranean climates. In: Osman A.E., Ibrahim M.H. and Jones M.A. (eds) The role of legumes in the farming systems of the Mediterranean areas, pp. 3-29. Dordrecht, The Netherlands: Kluwer Academic Publishers.

C ARTER E.D. (1978) A review of the existing and potential role of legumes in farming systems of the Near East and North African Region. Report for ICARDA. Adelaide, Australia: Waite Agricultural Research Institute.

Christiansen S., El Moneim A.M., Cocks P. and SinGH M. (1996) Seed yield and hardseededness of two amphicarpic pasture legumes (Vicia sativa ssp. amphicarpa and Lathyrus citiolatus) and two annual medics (Medicago rigidula and M. noena). Journal of Agricultural Science, Cambridge, 126, 421-427.

Christiansen S., Bounejmate M., Sawny-Edo H., Mawlawi B., Shomo F., Cocks P.S. and Nordblom T.N. (2000a) TAH village project in Syria: another unsuccessful attempt to introduce ley-farming in the Mediterranean basin. Experimental Agriculture, 36, 181193.

Christiansen S., Bounejmate M., Bahhady F., Thompson E., Mawlawi B. and Singh M. (2000b) On-farm trials with forage legume-barley compared with fallow-barley rotations and continuous barley in north-west Syria. Experimental Agriculture, 36, 195-204.

Christiansen S., Ryan J. and Singh M. (2011) Forage and food legumes in a multi-year wheat- based rotation under drought-stressed conditions in northern Syria's medium rainfall zone. Journal of Agronomy and Crop Science, 197, 146-154.
Cocks P.S., Mawlawi B. and Sawmy-Edo H. (1989) Introduction of ley farming system in Syrian villages. In: Christiansen S., Materon L., Falcinelli M and Cocks P. (eds) Introducing ley farming to the Mediterranean basin, pp. 52-64. Perugia, Italy: Proceedings, International Workshop, 26-30 June 1989.

Cooper P.J.M., Gregory P.J., Tully P.J. and Harris H.C. (1987) Improving water use efficiency of annual crops in the rainfed farming systems of West Asia and North Africa. Experimental Agriculture, 23, 113-158.

Crгв в J. (2010) The coming famine: the global food crisis and what we can do to avoid it. Victoria, Australia: CSIRO Publ., Collingwood, Melbourne, Australia.

Doberman A. and Cassman K.G. (2002) Plant nutrient management for enhanced productivity in intensive grain production systems of the United States and Asia. Plant and Soil, 247, 153-175.

El Moneim A.M. (1992) Narbon vetch (V. narbonensis L.): a potential feed legume crop for dry areas in West Asia. Journal of Agronomy and Crop Science, 169, 347352.

El Moneim A.M. (1993a) Agronomic potential of three vetches (Vicia spp.) under rainfed conditions. Journal of Agronomy and Crop Science, 170, 113-120.

El Moneim A.M. (1993b) Selection of non-shattering common vetch, Vicia sativa L. Plant Breeding, 110, 168171.

El Moneim A.M. and Bellar M. (1993) Response of forage vetches and forage peas to root-knot nematode (Meloidogyne artiellia) and cyst nematode (Heterodera ciceri). Nematologia Mediterranea, 21, 67-70.

El Moneim A.M. and Cocks P.S. (1986) Adaptation of Medicago rigidula to a cereal-pasture rotation in north-west Syria. Journal of Agricultural Science, Cambridge, 107, 179-186.

El Moneim A.M. and Cocks P.S. (1992) Adaptation and yield stability of selected lines of Lathyrus spp. under rainfed conditions. Euphytica, 66, 89-97.

El Moneim A.M., Khair M.A. and Rihawi S. (1990) Effect of genotypes and plant maturity on forage quality of certain forage legume species under rainfed conditions. Journal of Agronomy and Crop Science, 164, 85-92.

El Moniem A.M., Nakkoul H., Masri S. and Ryan J. (2010) Implications of zinc fertilization for ameliorating toxicity (lathyrism) in grasspea (Lathyrus sativus). Journal of Agricultural Science and Technology., 12, 69-78.

Ghassali F., Cocks P.S., Osman A.E., Gintzburger G., Christiansen S., Semane A. and Leybourne M. (1999) Rehabilitation of degraded grasslands in north Syria: use of farmer participatory research to encourage the sowing of annual pasture legumes. Experimental Agriculture, 35, 489-506.

Godfray H.C.D., Beddington J.R., Crute I.R., Haddad L., Lawrence D., Muir J.F., Pretty J., Robinson S., Thomas S.M. and Toulmin C. (2010) Food security: the challenges of feeding 9 billion people. Science, 327, 812-818.

GREUTER W. (1991) Botanical diversity, endemism rarity and extinction in the Mediterranean area: an analyses 
based on the published volumes of Med-Checklist. Botanica Chronica, 10, 63-79.

Halila M.H., Dahmane A.B.K. and Seklani H. (1990) The role of legumes in the farming systems of Tunisia. In: Osman A.E., Ibrahim M.H. and Jones M.A. (eds) The role of legumes in the farming systems of the Mediterranean areas, pp. 115-129. Dordrecht, The Netherlands: Kluwer Academic Publishers.

HARRIS H.E. (1995) Long-term trials on soil and crop management at ICARDA. Advances in Soil Science, 19, $447-469$.

Hopfenberg R. and Pimentel D. (2001) Human population numbers as a function of food supplies. Environment, Development and Sustainability, 3, 1-15.

Jones M.J. (2000) Comparison of conservation tillage systems in barley-cropping systems in northern Syria. Experimental Agriculture, 36, 195-204.

Jones M.J. and Singh M. (2000a) Long-term yield patterns in barley-based cropping systems in northern Syria. I. Comparison of rotations. Journal of Agricultural Science, Cambridge, 135, 223-236.

Jones M.J. and SINGH M. (2000b) Long-term yield patterns in barley-based cropping systems in northern Syria. 2. The role of feed legumes. Journal of Agricultural Science, Cambridge, 135, 237-249.

Karlen D.L. (1994) Crop rotations for the 21st century. Advances in Agronomy, 53, 1-45.

Kassam A.H. (1991) Climate, soil and land resources in North Africa and West Asia. Plant and Soil, 58, 1-29.

Keatinge J.D.H., Asghar A., Roidar K.B., El Moneim A.M. and Ahmed S. (1991) Germplasm evaluation of annual sown forage legumes and environmental conditions marginal for crop growth in highland of West Asia. Journal of Agronomy and Crop Science, 166, 48-57.

Khouri N., Shideed K. and Kherallah M. (2011) Food security: perspectives from the Arab World. Food Security, 3(Suppl. 1), S1-S6.

LAL R. (2002) Carbon sequestration in the dryland ecosystems of West Asia and North Africa. Land Degradation and Development, 13, 45-59.

Larbi A., Hassan S., Kattash G., El Moneim A.M., JAmmal B., NABil H. and NAKKUl H. (2010a) Annual feed legume yield and quality in dryland environments in north-west Syria: 2. Grain and straw yield and straw quality. Animal Feed Science and Technology, 160, 90-97.

Larbi A., Hassan S., Kattash G., El Moneim A.M., Jammal B., Nabil H. and Nakkul H. (2010b) Annual feed legume yield and quality in dryland environments in north-west Syria: 1. Herbage yield and quality. Animal Feed Science and Technology, 160, 81-89.

Le Houerou H.N. (2000) Restoration and rehabilitation of arid and semiarid Mediterranean ecosystems in North Africa and West Asia: a Review. Journal of Arid Soil Research and Rehabilitation, 14, 3-14.

Linke K.H., El Moneim A.M. and Saxena M.E. (1993) Variation in resistance of some forage legume species to Orobanche crenata Frosk. Field Crops Research, 32, 277285.
Lounaichi M. and Tastad A. (2010) The Syrian Steppe: past trends, current status and future priorities. Rangelands, 32, 2-7.

Louhaichi M., Ghassali F., Salkini A.K. and Petersen S.L. (2012) Effect of livestock grazing on rangeland plant communities within Syrian landscape depressions. Journal of Arid Environments, 79, 101-106.

MASRI Z. and RYAN J. (2006) Soil aggregation and related physical properties in a Mediterranean wheatbased, long-term rotation trial. Soil Tillage Research, 87, $146-154$.

Materon L. and Ryan J. (1995) Rhizobial inoculation and phosphorus and zinc nutrition of annual medics (Medicago spp.) adapted to Mediterranean-type environments. Agronomy Journal, 87, 692-698.

Mathison M.J. (1983) Mediterranean and temperate forage legumes. In: McIvor J.G. and Bray R.A. (eds) Genetic resources of forage plants, pp. 63-84. East Melbourne, Australia: CSIRO.

McCartney D. and Fraser J. (2010) The potential role of annual forage legumes in Canada: a review. Canadian Journal of Plant Science, 90, 403-420.

Nordblom L.T., Pannel D.J., Christiansen S., Nersoyan N. and BahHady F. (1994) From weed to wealth? Prospects for medic pastures in the Mediterranean farming system of north-west Syria. Agricultural Economics, 11, 29-42.

Norman H.C., Cocks P.S. and Galwey N.W. (2005) Annual clovers (Trifolium spp.) have different reproductive strategies to achieve persistence in Mediterranean-type climates. Australian Journal Agricultural Research, 56, 33-43.

ORAM P. and DE HAAN C. (1995) Technologies for rainfed agriculture in Mediterranean climate. A review of World Bank experiences. World Bank Technical Paper No. 300, Washington, DC: World Bank.

Pala M., Ryan J., Diekmann J. and Singh M. (2008) Influence of reduced tillage and compost application on crop yields in a cereal/forage legume rotation trial. Experimental Agriculture, 45, 1-12.

Papastylianou I. (1993) Nitrogen fixation by medics and their role in rotations and in marginal areas in Cyprus. In: Christiansen S., Materon L., Falcinelli M. and Cocks P. (eds.) Introducing ley farming to the Mediterranean basin. Proceedings, International Workshop, 26-30 June 1989, Perugia, Italy, pp. 99-105. Aleppo, Syria: ICARDA.

Polhill R.M. and van der Maesen L.J.G. (1985) Taxonomy of grain legumes. In: Summerfield R.J. and Roberts E.H. (eds) Grain legume crops, pp. 3-36. London: Collins.

Porqueddu C. and Sulas L. (1998) Mediterranean grassland systems. Grassland Science in Europe, 3, 335 345.

Puckidge D.W. and French R.J. (1983) The annual legume pasture in cereal-ley farming systems of Southern Australia: a review. Agriculture, Ecosystems and Environment, 9, 229-267.

Ratinam M., El Moneim A.M. and Saxena M.C. (1994) Variation in sugar content and dry matter 
distribution in roots and their associations with frost tolerance in certain forage legume species. Journal of Agronomy and Crop Science, 173, 345-353.

Rees D.J., Islam M., Samiullah A., Fahema R., Raza S.H., Quresh Z. and Mehmood S. (1991) Rainfed crop production systems of upland Baluchistan: wheat (Triticum aestivum), barley (Hordeum vulgare) and forage legumes (Vicia spp.). Experimental Agriculture, 27, 53-69.

Robertson L.D. and Bounejmate M. (1999) Genetic erosion of pasture and forage legumes in the Mediterranean basin. In: Bennett S.J. and Cocks P.S. (eds) Genetic resources of mediterranean pasture and forage legumes, (Current plant science and biotechnology in agriculture), pp. 67-77. Dordrecht, the Netherlands: Kluwer Academic Publishers. Vol. 33.

Robertson L.D., Singh K.B., ERSKine W. and EL Moneim A.M. (1996) Useful genetic diversity in germplasm collections of food and forage legumes from West Asia and North Africa. Genetic Resources and Crop Evolution, 43, 447-460.

Roy R.N., Finck A., Blair G.J. and TAndon H.S. (2006) Plant nutrition for food security: a guide to integrated nutrient management. FAO Fertilizer and Plant Nutrition Bulletin No. 16. Rome, Italy: Food and Agriculture Organization of the United Nations.

RyAn J. (ed.) (1997) Accomplishments and future challenges in dryland soil fertility research in the Mediterranean area. In: Proceedings International Soil Fertility Workshop 19-23 Nov. 1995, 369 pp. Aleppo, Syria: ICARDA.

RYAN J. (1998) Changes in organic carbon in long-term rotation and tillage trials in northern Syria. In: Lal R., Kimble J. M., Follett J. F. and Stewart B. A. (eds) Management of carbon sequestration in soil, pp. 285-295. Boca Raton, FL.

Ryan J., Masri S., Pala M. and Bounejmate M. (2002) Barley-based rotations in a typical Mediterranean ecosystem: crop production trends and soil quality. Options Mediterraneennes, 50, 287-296.

Ryan J., Hasbany R. and Atallah T. (2003) Factors affecting nitrogen mineralization under laboratory conditions with soils from a wheat-based rotation trial. Lebanese Science Journal, 2, 3-12.

Ryan J., Singh M. and Pala M. (2008a) Long-term cereal-based rotation trials in the Mediterranean region. Implications for cropping sustainability. Advances in Agronomy, 97, 276-324.

Ryan J., Masri S., Ibrikci H., Pala M., Singh M. and HARRIS H. (2008b) Implications of cereal-based rotations, nitrogen fertilization, and crop residues on soil organic matter under Mediterranean conditions. Turkish Journal of Agriculture and Forestry, 32, 289 297.

Ryan J., Masri S., Singh M., Pala M. and Ibrikci H. (2008c) Total and mineral nitrogen in a wheat-based rotation under dryland Mediterranean conditions. Basic and Applied Dryland Research, 2, 34-46.

Ryan J., Pala M., Masri S., Singh M. and Harris H. (2008d) Rainfed-based wheat rotations under Mediterranean conditions: crop sequences, nitrogen fertilization, and stubble grazing in relation to grain and straw quality. European Journal of Agronomy, 28, 112-118.

RYAN J., MASRI S. and SiNGH M. (2009a) Nutrient dynamics in a long-term cereal-based rotation trial in a Mediterranean environment: Nitrogen forms.

Communications in Soil Science and Plant Analysis, 40, 188199.

Ryan J., Masri S., Pala M. and Singh M. (2009b) Seasonal changes in organic matter and biomass and labile forms of carbon as influenced by Mediterranean crop rotations. Communications in Soil Science and Plant Analysis, 40, 931-946.

Ryan J., Pala M., Harris H., Masri S. and Singh M. (2010) Rainfed wheat-based rotations under Mediterranean-type climatic conditions: crop sequences, $\mathrm{N}$ fertilization, and stubble grazing intensity in relation to cereal yield parameters. Journal of Agricultural Science, Cambridge, 148, 205-216.

Ryan J., Christiansen S. and Singh M. (2012) Assessment of long-term barley-legume rotations in a typical Mediterranean agro-ecosystem: grain and straw yields. Archives of Agronomy and Soil Science, 58, 233-246.

Stewart B.A. and Robinson C.A. (1997) Are ecosystems sustainable in semiarid regions? Advances in Agronomy, 60, 191-228.

SulAs L. (2005) The future role of forage legumes in Mediterranean climate areas. In: Reynolds S.G. and Frame J. (eds) Grasslands: developments, opportunities, perspectives, pp. 29-54. Rome: FAO and Plymouth UK: Science Publishers Inc.

Sultan K., Gintzburger G., Obaton M., Robin C., Touchane H. and Guckert A. (2001) Growth and nitrogen fixation of annual Medicago-Rhizobium associations during winter in Mediterranean region. European Journal of Agronomy, 15, 221-229.

Thompson E.F., Jaubert R. and OgLah M. (1992) Using on farm trials to study the benefits of feed legumes in barley based rations in north-west Syria. Experimental Agriculture, 28, 143-154.

Yau S.K., Bounejmate M., Ryan J., Nassar A., BAALBAKI R. and MACCAROUN R. (2003) Sustainable barley - legume rotation for semi-arid areas of Lebanon. European Journal of Agronomy, 19, 599-610.

Zoghlami A., Hassan H., Seklani H., Robertson L. and Salkini A.K. (1996) Distribution des luzernes annuelles en Tunisie central en function des facteurs edaphiques climatiques. [Distribution of annual medics in central Tunisia in relation to edaphic and climatic factors] Fourrages, 145, 5-16. 